\title{
The Effect of Fetal Thyroidectomy on Ovine Fetal Lung Maturation
}

\author{
ALLEN ERENBERG, ${ }^{(57)}$ MITCHELL L. RHODES, MARY M. WEINSTEIN, AND \\ ROLAND L. KENNEDY \\ Departments of Pediatrics, Internal Medicine, and Anesthesia, University of Iowa Hospitals and Clinics, Iowa City, \\ Iowa, USA
}

\begin{abstract}
Summary
Studies were conducted to assess the effect of fetal thyroidectomy early in the third trimester on lung growth and surfactant maturation in the sheep. At 95-99 days of gestation, a fetal thyroidectomy was performed. The preparation was killed 36-45 days postthyroidectomy. The mean weights of the cerebrum, cerebellum, and combined heart and lungs were significantly smaller and the pituitary gland significantly greater in the thyroidectomized fetus. The mean tracheal fluid lecithin to sphingomyelin (L/ S) ratio was significantly lower in the athyrotic fetus; however, there was no significant difference in the mean cortisol concentration or mean whole lung homogenate phosphatidic acid phosphohydrolase (PAPase) specific activity between the two groups. There was a significant direct correlation between the serum cortisol concentration and tracheal fluid $L / S$ ratio and between the whole lung homogenate PAPase specific activity and serum cortisol level in the euthyroid group, which were not present in the thyroidectomized group. The mean lung DNA concentration was significantly increased and mean lung protein/DNA ratio significantly decreased in the thyroidectomized fetus. On histologic examination, the lung from the athyrotic fetus was hypercellular with thickened alveolar septae. The type II pneumocyte in the hypothyroid lung was less mature with fewer lamellar bodies or its precursors. These results suggest that in the ovine fetus, thyroid hormone deficiency during the last trimester of intrauterine development impairs lung growth and surfactant maturation.
\end{abstract}

\section{Speculation}

The present results suggest that thyroid hormones are necessary for normal lung growth and surfactant maturation. In the human preterm infant, idiopathic respiratory distress syndrome is a major cause of morbidity and mortality. Stimulation of the hypothalamicpituitary-thyroid axis in the fetus at high risk for developing idiopathic respiratory distress syndrome before delivery may accelerate surfactant maturation and decrease the sequelae from this syndrome.

Recent studies have demonstrated that the fetal endocrine systems play a major role in lung maturation (3). After Dr. Liggin's work demonstrating that direct administration of dexamethasone to the ovine fetus accelerates lung maturation, subsequent studies have further delineated the interrelationship of the glucocorticoids and fetal lung development $(14,17,28,30,33,37,42,48,49,53)$. In humans, administration of betamethasone to the gravida in premature labor has decreased the incidence and mortality from the idiopathic respiratory distress syndrome in her infant (31).

Less is known, however, of the role of the iodothyronines on lung growth and surfactant synthesis. Direct injection of thyroxine $\left(\mathrm{T}_{4}\right)$ into the fetal rabbit will accelerate lung maturation (54), while surgical thyroidectomy performed at midgestation in the ovine fetus will alter lung growth (19). Electronmicrographs of type II pneumocytes from hypothyroid fetal and adult rats dem- onstrate decreased cell size, clumping of chromatin, increased glycogen content and decreased number of osmiophilic inclusion bodies $(7,38)$. In human neonates with idiopathic respiratory distress syndrome, cord thyroid hormone concentrations are lower than in healthy infants of comparable gestational age $(12,39)$. The studies in the present report were conducted to assess the effect of fetal thyroidectomy early in the third trimester on lung growth and surfactant maturation in the sheep.

\section{MATERIALS AND METHODS}

\section{DESCRIPTION OF THE ANIMAL MODEL}

Columbia and Columbia-Suffolk date-bred ewes were obtained from a local source, maintained at the University vivarium and given free access to alfalfa and water. At 95-99 days of gestation, under epidural anesthesia, the uterus was exposed through a lower midabdominal incision in five ewes with singleton pregnancies. After isolation of the fetal head, the uterus was incised and a fetal thyroidectomy performed. No more than 2-3 cotyledons were killed at the time of surgery. The fetus was returned to the uterus and the surgical incision repaired in layers. Postoperatively, all ewes were feeding within $2 \mathrm{hr}$ of completion of surgery and maintained their weight and general health. At 137-142 days of gestation, 36-45 days postthyroidectomy, the ewe was placed under spinal anesthesia (term $=145-150$ days). Through a lower midabdominal incision, the uterus was incised and the fetal head isolated. An incision was made into the fetal neck and the trachea isolated and ligated. After blood and tracheal fluid sampling, the preparation was killed and a complete autopsy performed on the fetus. After weighing each organ, the tissue was quick frozen and stored at $-70^{\circ}$.

\section{PREPARATION OF THE LUNG TISSUE FOR HISTOLOGIC} EXAMINATION

The heart and lungs were removed in toto to facilitate preparation of the tissue for histologic examination. After weighing, the right main stem bronchus was isolated and ligated and the right lung separated and used for measurement of protein, DNA, and PAPase specific activity. The left lung was perfused with a $2.5 \%$ gluteraldehyde solution at $25 \mathrm{~mm} \mathrm{Hg}$ pressure through the trachea and right ventricle. After rinsing in cacodylate buffer, a portion of the lung was taken for light microscopy. Another portion of the lung was minced into $1-\mathrm{mm}$ cubes and postfixed in $2 \%$ osmium tetroxide. The tissue was then dehydrated through graded alcohols, embedded in spurrs epon, and sectioned with a diamond knife on a LKB Ultramicrotome III. Sections were picked up on a copper grid, stained with Reynolds lead stain and uranyl acetete, and examined in a Phillips 300 electron microscope.

\section{ASSAYS AND BIOCHEMICAL STUDIES}

Serum $\mathbf{T}_{4}$ concentrations were measured, in duplicate, in $25 \lambda$ unextracted serum samples by radioimmunoassay (10). The tra- 
cheal fluid L/S ratio was determined by thin layer chromatography (45). Serum cortisol levels were measured in triplicate on 100 $\lambda$ serum samples by ligand double antibody radioimmunoassay (reagents obtained from Diagnostic Products Corp., Los Angeles, CA). Lung protein concentrations were measured by the method of Schacterle and Pollock (43) and lung DNA concentrations were measured by the method of Richards (40). PAPase (EC 3.1.3.4.) specific activity was measured in whole lung homogenates by a modification of the method of Coleman and Hübscher (11).

The data from the five thyroidectomized fetuses was compared to five euthyroid animals from singleton pregnancies of 138-142 days of gestation. The euthyroid fetuses were operated upon at 95-99 days of gestation for other experiments which were not designed to induce growth retardation or would have induced stress in the fetus. None of the ewes in either study group were in labor at the time of killing, and all animals were killed at the same time of the day. Student's $t$ test was used to assess the significance of the differences between the results found in the euthyroid and hypothyroid fetuses.

\section{RESULTS}

Although the mean gestational age $( \pm S E M)$ was similar in the euthyroid and hypothyroid fetuses $(140 \pm 0.8$ vs. $139 \pm 0.8$ days, respectively), the mean body weight was significantly less in the thyroidectomized fetus ( 3.0 vs. $4.46 \mathrm{~kg}, P<0.005)$. The wet weight of selected organs from the euthyroid and thyroidectomized fetuses are listed in Table 1 . The mean weights of the cerebrum, cerebellum, and combined heart and lungs were significantly smaller and the pituitary gland significantly greater in the thyroidectomized fetus. Although the mean weight of the adrenal glands was less in the thyroidectomized animal, this difference was not significant. Mean serum $\mathrm{T}_{4}$ and cortisol concentrations, tracheal fluid $\mathrm{L} / \mathrm{S}$ ratio and whole lung homogenate PAPase specific activity in euthyroid and thyroidectomized fetuses at the time of sacrifice are shown in Table 2 . There was no remaining visible thyroid tissue and the serum $\mathrm{T}_{4}$ concentration was below the sensitivity of the radioimmunoassay in all five thyroidecto- mized fetuses. The mean tracheal fluid $\mathrm{L} / \mathrm{S}$ ratio was significantly lower in the athyrotic fetus; however, there was no significant difference in the mean serum cortisol concentration or mean whole lung homogenate PAPase specific activity between the two groups.

As seen in Figure 1, there was a significant direct correlation between the serum cortisol concentration and tracheal fluid $\mathrm{L} / \mathrm{S}$ ratio in the euthyroid group $(r=0.958, P=<0.01)$, which was not present in the thyroidectomized group $(r=0.594, P=>0.1)$. Although a significant direct correlation between the whole lung homogenate PAPase specific activity and serum cortisol level was present in the euthyroid group $(r=0.988, P=<0.001)$, it was not seen in the athyrotic group $(r=0.345, P=>0.1)$.

The protein and DNA concentrations and protein/DNA ratio in lung tissue from euthyroid and thyroidectomized fetuses are

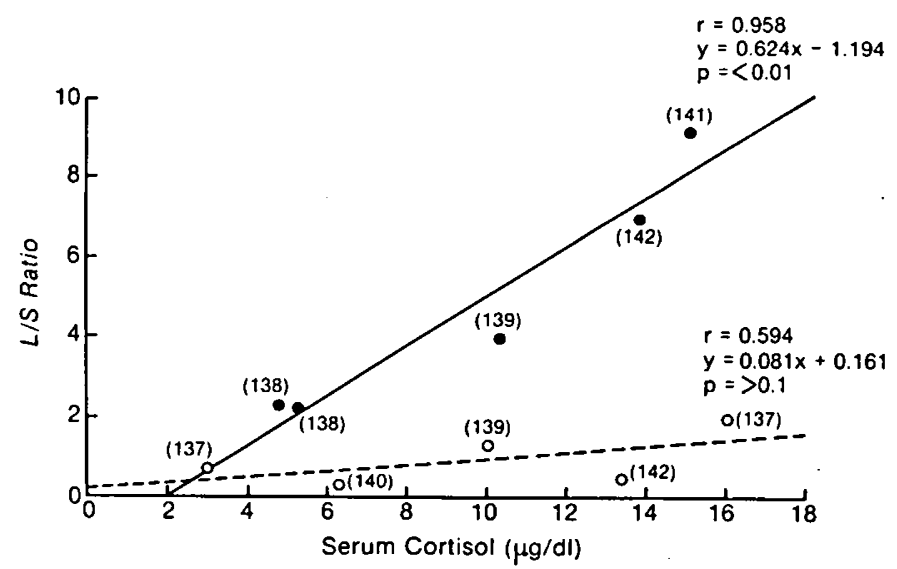

Fig. 1. Relationship between serum cortisol concentration and tracheal fluid L/S ratio in five euthyroid ovine fetuses (solid circles and line) and five hypothyroid ovine fetuses (open circles and dotted line). The numbers in parentheses are the gestational ages of the fetuses at the time they were killed.

Table 1. Wet weight $(g)$ of selected organs of euthyroid and thyroidectomized ovine fetuses

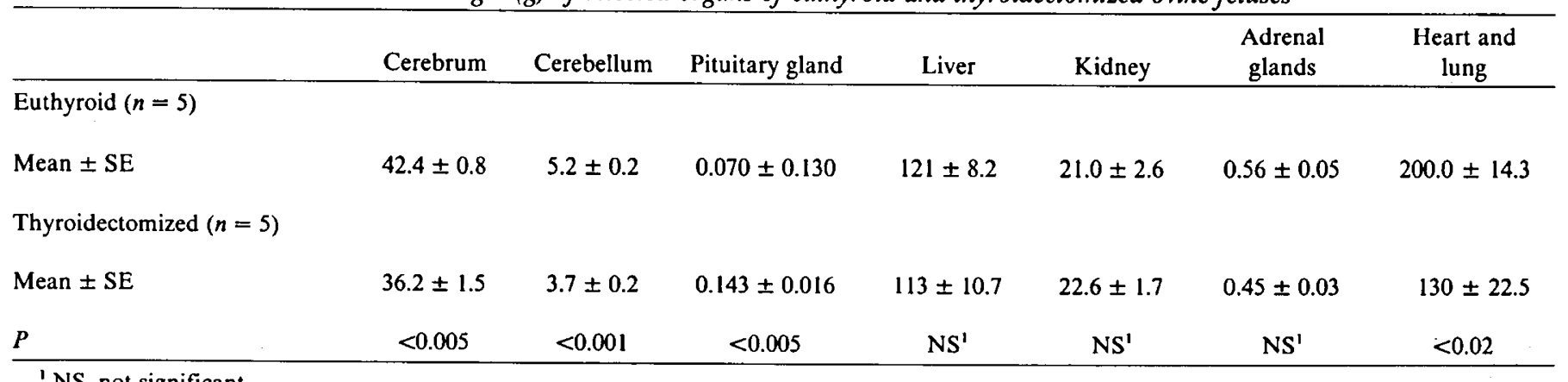

'NS, not significant.

Table 2. Serum thyroxine and cortisol concentration, tracheal fluid $L / S$ ratio and whole lung homogenate PAPase specific activity in euthyroid and thyroidectomized fetuses

Serum thyroxine concentration Serum cortisol concentration $(\mu \mathrm{g} / \mathrm{dl})$

Euthyroid $(n=5)$

Mean $\pm \mathrm{SE}$

$14.2 \pm 2.2$ $(\mu \mathrm{g} / \mathrm{dl})$

$9.8 \pm 2.1$

$4.9 \pm 1.4$

$0.016 \pm 0.006$

Thyroidectomized $(n=5)$

Mean $\pm \mathrm{SE}$

$<1$

$9.8 \pm 2.3$

$1.0 \pm 0.3$

$0.021 \pm 0.005$

$P$

$<0.001$

NS ${ }^{1}$

$<0.001$

$N S^{1}$

'NS, not significant.

PAPase specific activity

$\left(\frac{\mu \mathrm{mol} p}{\mathrm{mg} \text { protein } \cdot \mathrm{hr}}\right)$ 
shown in Table 3. The mean lung DNA concentration was significantly increased and mean lung protein/DNA ratio significantly decreased in the thyroidectomized fetus, indicating that the thyroidectomized fetal lung consists of a larger number of smaller sized cells, consistent with the hypercellular histologic appearance of this lung.

A photomicrograph comparing the fetal lung from the euthyroid and athyrotic fetus is seen in Figure 2. Compared to the euthyroid animal, the lung from the athyrotic fetus is hypercellular with thickened alveolar septae. Budding is present in the bronchioles, a characteristic seen in the canalicular stage of fetal lung development usually present at 120-130 days of gestation in the fetal sheep. The electron photomicrograph seen in Figure 3 further demonstrates the differences in cellularity and alveolar septal thickness between the two groups. Type II pneumocytes from both lungs are compared in Figure 4. In the euthyroid lung, this cell contains many lamellar bodies and its precursors, tubules and vesicles, while the cell from the hypothyroid lung is less mature with fewer lamellar bodies or its precursors.

There were no significant differences in mean maternal weight, serum $\mathrm{T}_{4}$, or cortisol concentrations between the two groups.

Table 3. Protein and DNA concentration and protein/DNA ratio in lung tissue of euthyroid and thyroidectomized fetuses

\begin{tabular}{lccc}
\hline & $\begin{array}{c}\text { Protein (mg/g wet } \\
\text { weight lung) }\end{array}$ & $\begin{array}{c}\text { DNA (mg/g wet } \\
\text { weight lung) }\end{array}$ & Protein/DNA \\
\hline Euthyroid $(n=5)$ & & & \\
Mean \pm SE & $62.9 \pm 2.8$ & $7.4 \pm 0.3$ & $8.1 \pm 0.3$ \\
$\begin{array}{l}\text { Thyroidectomized } \\
(n=5)\end{array}$ & & & \\
Mean \pm SE & $64.7 \pm 8.1$ & $9.2 \pm 0.5$ & $6.7 \pm 0.2$ \\
$P$ & $\mathrm{NS}$ & $<0.01$ & $<0.005$ \\
\hline
\end{tabular}

${ }^{'}$ NS, not significant.

\section{DISCUSSION}

In ovine fetus, the hypothalyamic-pituitary-thyroid axis functions automonously from the maternal system. At approximately 50 days of gestation, the ovine fetal thyroid gland begins to accumulate iodine (4) and $T_{4}$ and thyroid stimulating hormone are present in fetal serum (51). Follicular organization is seen at 50 days of gestation, with histologic features of the adult gland present at 115 days $(4,51)$. Within 3 days after surgical thyroidectomy, serum $T_{4}$ concentrations rapidly fall to the hypothyroid range (18). The maternal to fetal placental transfer of $T_{4}$ and triiodothyronine $\left(\mathrm{T}_{3}\right)$ is minimal in the athyrotic fetus, providing less than $3 \%$ of the estimated daily combined fetal $T_{4}$ and $T_{3}$ requirements $(16,18)$. Thus, the thyroidectomized fetus in this study was exposed to minute quantities of iodothyronines during the third trimester when the euthyroid fetal hypothalamic-pituitary-thyroid axis is functional.

Our results of the effect of surgical thyroidectomy on somatic growth in the ovine fetus are similar to those reported by investigators using a similar animal model $(6,19,24)$. The mean combined fetal heart and lung weight was statistically less in the thyroidectomized fetus (Table 1). Bhakthavathsalan et al. (6) have reported that the mean lung weight in the thyroidectomized ovine fetus was less when compared to the euthyroid animal, but this difference was not statistically significant. In their study, the fetal thyroidectomy was performed at a later gestational age, and their fetuses may have been euthyroid during the stage of development when iodothyronines are necessary for normal lung growth.

Dramatic changes in functional and biochemical parameters normally occur in the ovine fetal lung at 120-130 days of gestation. Lungs from fetal lambs less than 120 days of gestation have poor distensibility, with more mature mechanical properties appearing at $120-130$ days $(9,21)$. Although types I and II epithelial cells become more distinguishable at 110 days, osmiophilic inclusion bodies, thought to be the storage organelle for surfactant, appear at 120 days and rapidly increase in number at 135 days of gestation (29). The histologic examination of the thyroidectomized fetal lung tissue demonstrates that its morphologic maturation is delayed, being comparable to that seen during the canalicular stage in the euthyroid ovine fetus (Figs. 2-4). Electron microscopic
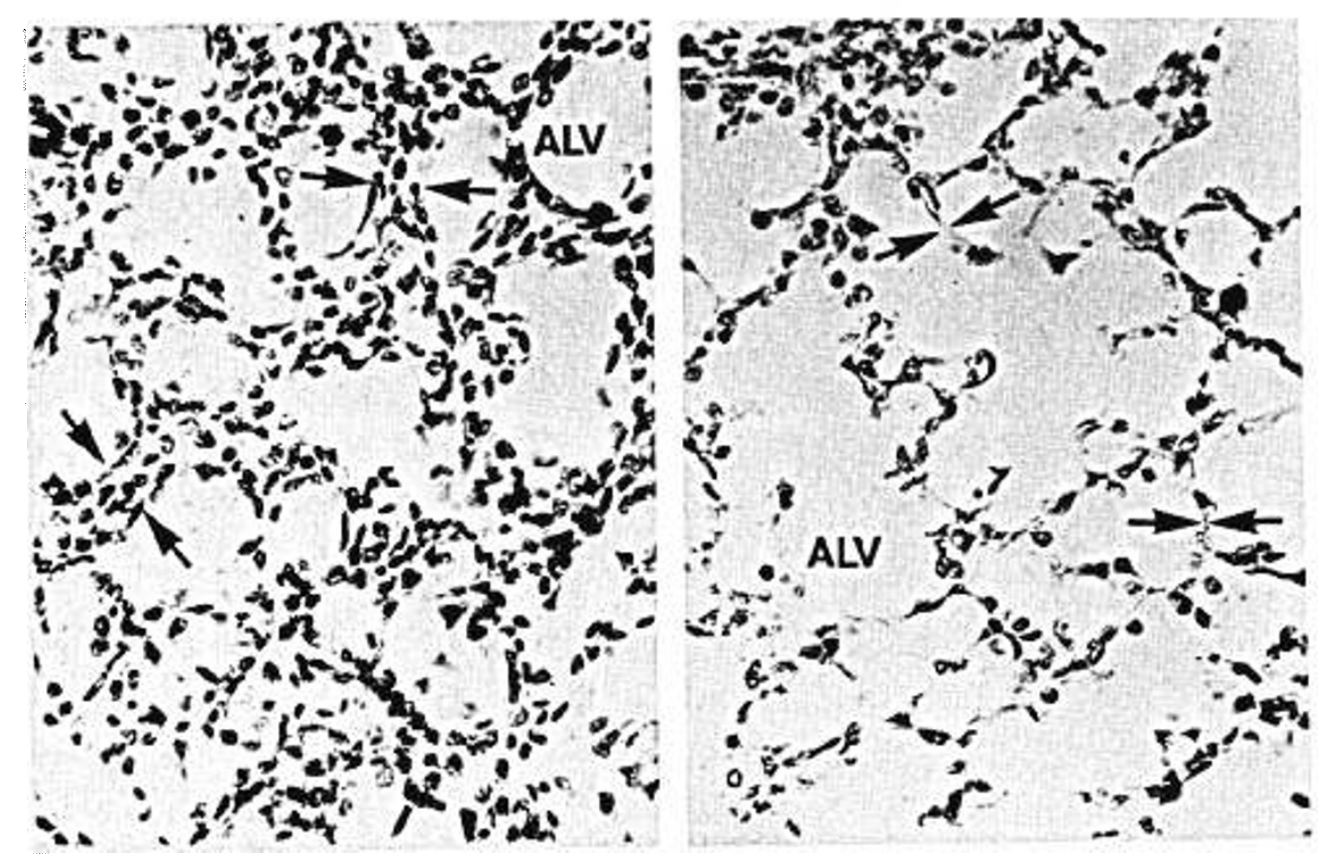

Fig. 2. High power photomicrograph of ovine fetal lung tissue from a hypothyroid fetus (left) of 140-day gestation and euthyroid fetus (right) of 139day gestation. The lung from the euthyroid animal (right) shows well developed alveolar spaces $(A L V)$ and their alveolar walls (arrows) contain only scattered nuclei. In the athyrotic fetal lung (left), the thickening of the septal walls (arrows) is due to the hypercellularity of the interstitium. Cuboidal cells are projecting into the alveolar spaces. (Original magnification $\times 400$ ). 

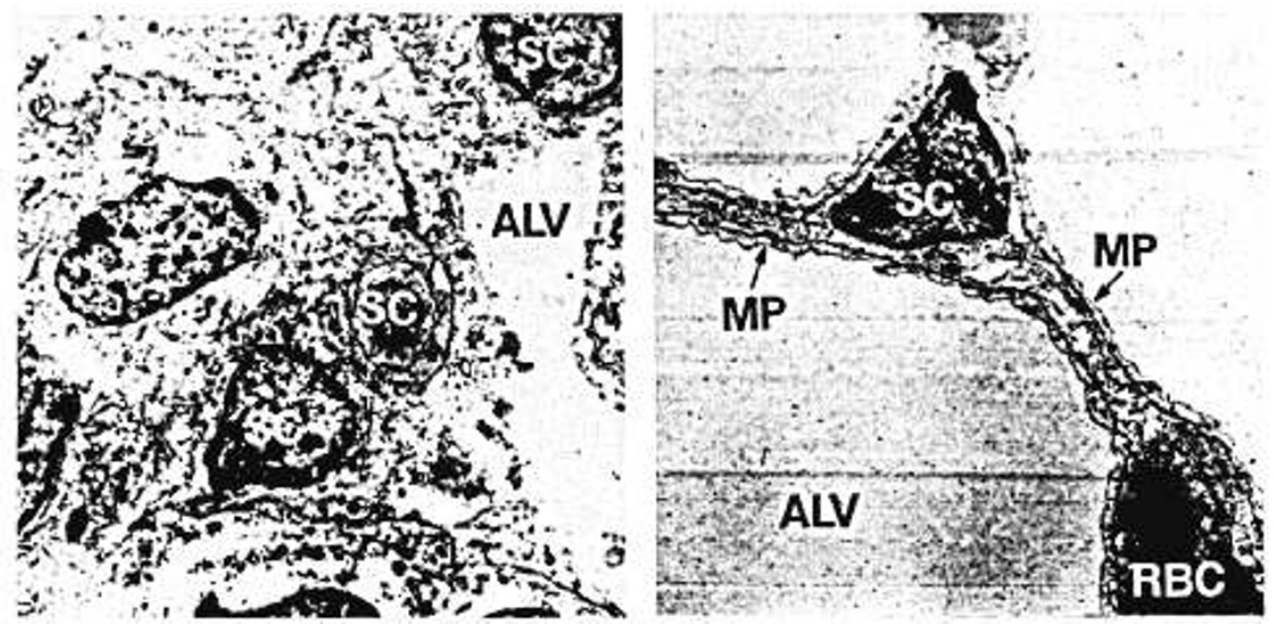

\section{$\stackrel{\longmapsto}{1 \mu}$}

Fig. 3. Electronmicroscopic study of the alveolar septum from the hypothyroid (left) and euthyroid (right) ovine fetal lung. In the athyrotic lung, the alveoli are lined by simple cuboidal cells which have thin cytoplasmic extensions over the basement membrane. Three septal cells (SC) are seen in the central interstitial area. Three alveoli $(A L V)$ are seen separated by a mature appearing alveolar wall in euthyroid fetal lung. The alveolar lining consists of the thin cytoplasm of the membranous pneumocytes $(M P)$ covering the basement membrane. A single septal cell is present at the junction of the three alveoli, and red blood cells $(R B C)$ are seen in capillaries (original magnification $\times 3400$ ).
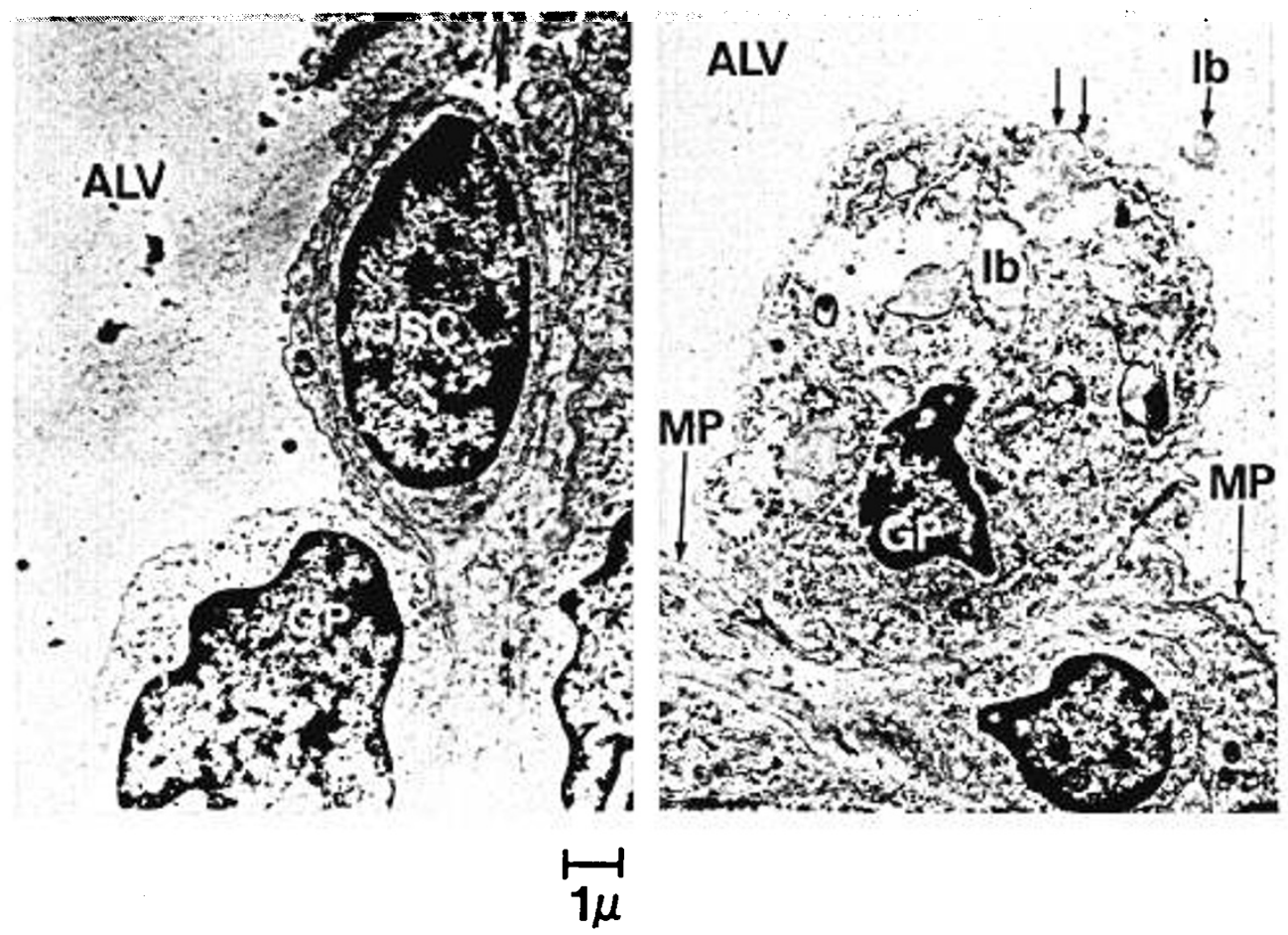

Fig. 4. Electronmicroscopic comparison of type II pneumocytes (GP) from hypothyroid (left) and euthyroid (right) ovine fetal lungs. In the euthyroid fetus, the type II pneumocyte contains many lamellar bodies (lb). Myelin material appears to be extruded in the alveolar space ( $A L V$ from the cell apex (double arrows). In the athyrotic fetal lung, the type II pneumocyte is a simple cuboidal cell, devoid of microvilli, inclusions, or organelles. This type of cell is seen several weeks earlier in ovine fetal lung development (original magnification $\times 4900$ ).

examination of the type II pneumocyte in the hypothyroid fetal lung reveals an immature cuboidal cell with few tubules, vesicles, or lamellar bodies. During the canalicular stage, the uptake of radioiodine-labeled thyroxine in the ovine fetal lung is greater than at term (35). Throughout the third trimester, the mean per kilogram fetal $\mathrm{T}_{4}$ secretion and clearance rates are 8 times that of its mother $(16,20)$. The significant reduction in weight and protein/DNA ratio, and delayed maturation seen on lung histology during the time of active fetal thyroid gland activity suggests that iodothyronines may be necessary for the morphologic maturation and growth of the ovine fetal lung during the last trimester of gestation.

Surfactant is detectable in fetal tracheal fluid between 124-133 of days and its secretion increases rapidly after 135 days of gestation (32). Our result of impaired surfactant production as manifest by a significantly lower tracheal fluid L/S ratio and decreased number of surfactant containing lamellar bodies in the type II pneumocyte in the athyrotic fetus is consistent with the 
data reported by Cunningham et al. (13). The cretin fetal lamb delivered at term dies of respiratory failure soon after birth (13, 52). After the onset of spontaneous respirations, the neonatal cretin lamb forms surfactant with an abnormal phosphatide composition and releases predominately acidic pulmonary phospholipids with poor surfactant-like activity (13). Although human neonates with idiopathic respiratory distress syndrome have been found to have lower serum $T_{4}$ and $T_{3}$ concentrations at birth and during the first 4 weeks of life $(1,39)$, the relationship of the iodothyronines and surfactant production and metabolism in these infants has not been studied.

The principle pulmonary surfactant in the fetal lamb, thought to be disaturated dipalmityl phosphatidylcholine, increases sharply in concentration in both the alveolar space and lung tissue at 120-130 days and to a lesser extent in the term lung (21). Ovine fetal serum glucocorticoid levels are low until 130-135 days of gestation when they increase rapidly until term (32). Until 135 days of gestation, maternal to fetal placental transfer may be the major souce of fetal glucocorticoids (27). At 140 days of gestation, the precipitious rise in ovine serum cortisol concentration is accompanied by an increase in the fetal cortisol production and metabolic clearance rates (34). Since the appearance of surfactant in both lung tissue and tracheal fluid precedes the rise of the serum cortisol level, glucocorticoids may not be the hormones responsible for the initial release of surfactant into the alveolus, but may cause an increase in surfactant synthesis. Other hormones, such as the iodothyronines, may be the stimulus for the appearance of surfactant in the ovine fetal lung and tracheal fluid.

Our study has shown that the mean serum cortisol concentration was similar in both groups of fetuses (Table 2). In man, hypothyroidism is associated with decreased cortisol metabolic clearance and production rates but a normal serum cortisol concentration (36). The serum half-life of total, bound, and unbound cortisol in hypothyroidism is unrelated to alterations in the plasma protein binding of cortisol (5) and the corticosteroid binding level is normal (15). Iodothyronines affect cortisol metabolism by influencing the hepatic conversion of the active hormone cortisol to the inactive metabolite, cortisone (23). Cortisone may affect fetal lung maturation as the fetal rabbit and human lung are able to convert cortisone to cortisol in vitro $(22,45,53)$. Iodothyronines may influence surfactant synthesis through its interaction with glucocorticoids in the fetal liver or lung.

Thyroxine, when added to fetal rabbit lung cells in culture, enhances the intracellular incorporation of choline into lecithin and its release into the media (47), but does not accelerate the uptake of lipid precursors or decelerate DNA synthesis in pulmonary explants from adult and fetal mice (2). Moreover, thyroxine has not been shown to affect any of the enzymes involved in surfactant synthesis (41). Phosphatidic acid, which plays a major role in all de novo pathways for the biosynthesis of phospholipids, is converted to sn 1, 2-diglycerides and orthophosphate by hydrolytic cleavage catalyzed by the enzyme PAPase (EC 3.1.3.4). This enzyme has been shown to be a key component in surfactant synthesis $(25,26,44,50)$, but there are no previous studies concerning its relationship with the iodothyronines. No significant difference in the whole lung homogenate PAPase specific activity was seen between the thyroidectomized and euthyroid ovine fetal lung (Table 2). There was a significant direct correlation between the serum cortisol concentration and whole lung homogenate PAPase specific activity in the euthyroid fetus similar to the results reported by Brehier et al. (8) in the euthyroid fetal rabbit. In one athyrotic fetus, the whole lung homogenate PAPase specific activity was elevated, but the serum cortisol concentration was low. The other four athyrotic fetuses showed a similar relationship between the whole lung homogenate PAPase specific activity and serum cortisol concentration as seen in the euthyroid fetus. Although the number of animals in this study are small, it appears that the influence of iodothyronines on pulmonary surfactant synthesis is not related to its interaction with the enzymes involved in surfactant synthesis.

\section{CONCLUSION}

Fetal thyroidectomy was performed in five ovine fetuses at 95 99 days and killed at 137-142 days of gestation. Mean body and combined heart and lung weights were significantly smaller in the athyrotic compared to the euthyroid fetus. The mean serum cortisol level and whole lung homogenate PAPase specific activity were similar in both groups, but mean tracheal fluid $\mathrm{L} / \mathrm{S}$ ratio was significantly lower in the athyrotic fetus. Compare to the euthyroid fetus, the mean lung DNA concentration was significantly increased and mean lung protein/DNA ratio significantly decreased in the thyroidectomized animal. Light and electromicroscopic studies of lung tissue demonstrated a delay in maturation in the hypothyroid fetus. These results suggest that, in the ovine fetus, thyroid hormone deficiency during the last trimester of intrauterine development impairs lung growth and surfactant maturation.

\section{REFERENCES AND NOTES}

1. Abbassi, V., Merchant, K., and Abramson, D.: Postnatal triiodothyronine concentrations in healthy preterm infants and in infants with respiratory distress syndrome. Pediatr. Res., 11: 802 (1977).

2. Adamson, I. Y. R., and Bowden, D. H.: Reaction of cultured adult and fetal lung to prednisolone and thyroxine. Arch. Pathol. 99: 80 (1975).

3. Avery, M. E.: Pharmacologic approaches to the acceleration of fetal lung maturation. Br. Med. Bull. 31: 13 (1975).

4. Barnes, C. M., Warner, D. E., Marks, S., and Busted, L. K.: Thyroid function in fetal sheep. Endocrinology, 60: 325 (1957).

5. Beisel, W. R., Diraimondo, V. C., Chao, P. Y., Rosner, J. M., and Forsham, P. H.: The influence of plasma protein binding on the extra-adrenal metabolism of cortisol in normal, hyperthyroid and hypothyroid subjects. Metabolism. 13: 942 (1964).

6. Bhakthavathsalan, A., Mann, L. I., Ayromloovi, J., Kunzel, W., and Liu, M.: The effects of fetal thyroidectomy in the ovine fetus. Am. J. Obstet. Gynecol., 127: 278 (1977).

7. Blackburn, W. R., Travers, H., and Potter, D. M.: The role of the pituitaryadrenal-thyroid axes in lung differentiation. I. Studies of the cytology and physical properties of anencephalic fetal rat lung. Lab. Invest., 26: 306 (1972).

8. Brehier, A., Benson, B. J., Williams, M. C., Mason, R. J., and Ballard, P. L.: Corticosteroid induction of phosphatidic acid phosphatase in fetal rabbit lung. Biochem Biophys. Res. Commun., 77: 883 (1977).

9. Brumley, G. W., Chernick, V., Hodson, W. A., Normand, C., Fenner, A., and Avery. M. E.: Correlation of mechanical stability, morphology, pulmonary surfactant and phospholipid content in the developing lamb lung. J. Clin. Invest., 46: 863 (1967).

10. Chopra, I. J.: A radioimmunoassay for measurement of thyroxine in unextracted serum. J. Clin. Endocrinol. Metab., 34: 938 (1972).

11. Coleman, R., and Hübscher, G.: Metabolism of phospholipids. V. Studies of phosphatidic acid phosphatase. Biochim. Biophys. Acta, 56: 479 (1962).

12. Cuestas, R. A., Lindall, A., and Engel, R. R.: Low thyroid hormones and respiratory-distress syndrome of the newborn. N. Engl. J. Med., 295: 297 (1976).

13. Cunningham, M. D., Hollingsworth, D. R., and Belin, R. P.: Impaired surfactant production in cretin lambs. Pediatr. Res., 11: 424 (1977).

14. De Lemos, R. A., Shermeta, D. W., Knelson, J. H., Kotas, R., and Avery, M. E.: Accleration of appearance of pulmonary surfactant in the fetal lamb by administration of corticosteroids. Am. Rev. Respir. Dis., 102: 459 (1970).

15. Doe, R. P., Fernandez, R., and Seal, U. S.: Measurement of corticosteroidbinding globulin in man. J. Clin. Endocrinol. Metab., 24: 1029 (1964).

16. Dussault, J. H., Hobel, C. J., and Fisher, D. A.: Maternal and fetal thyroxine secretion during pregnancy in the sheep. Endocrinology $88: 47$ (1971).

17. Ekelund, L.. Arvidson, G., and Astedt, B.: Cortisol induced accumulation of phospholipids in organ culture of human fetal lung. Scand. J. Clin. Lab. Invest., 35: 419 (1975).

18. Erenberg, A., Omori, K., Oh, W., and Fisher, D. A.: The effect of fetal thyroidectomy on thyroid hormone metabolism in maternal and fetal sheep. Pediatr. Res., 7: 780 (1973).

19. Erenberg, A., Omori, K., Menkes, J. H., Oh, W., and Fisher, D. A.: Growth and development of the thyroidectomized ovine fetus. Pediatr. Res., 8: 783 (1974).

20. Fisher, D. A., Dussault, J. H., Erenberg, A., and Lam, R. W.: Thyroxine and triiodothyronine metabolism in maternal and fetal sheep. Pediatr. Res., 6: 894 (1972).

21. Fujiwara, T., Adams, F. H., Sipos, S., and El-Salawy, A.: "Alveolar" and whole lung phospholipids of the developing fetal lamb and lung. Am. J. Physiol., 215: 375 (1968).

22. Giannopoulos, G.: Uptake and metabolism of cortisone and cortisol by the fetal rabbit lung. Steroids, 23: 845 (1974).

23. Gordon, G. G., and Southern, A. L.: Thyroid-hormone effects on steroid-hormone metabolism. Bull N Y Acad Sci, 53: 241 (1977).

24. Hopkins, P. S., and Thorburn, G. D.: The effect of foetal thyroidectomy on the development of the ovine fetus. J. Endocrinol. 54: 55 (1972).

25. Jimenez, J. M., Schultz, F. M., MacDonald, P. C., and Johnston, J. M.: Fetal lung maturation. II. Phosphatidic acid phosphohydrolase in human amniotic 
fluid. Gynecol. Invest., 5: 245 (1974).

26. Jimenez, J. M., Schultz, F. M., and Johnston, J. M.: Fetal lung maturation. III. Amniotic fluid phosphatidic acid phosphohydrolase (PAPase) and its relation to the lecithin/sphingomyelin ratio. Obstet. Gynecol., 46: 588 (1975).

27. Jones, C. T., Boddy, K., Robinson, J. S., and Radcliffe, J. C.: Developmental changes in the responses of the adrenal gland of foetal sheep to endogenous adrenocorticotrophin, as indicated by hormone responses to hypoxemia. J. Endocrinol., 72: 279 (1977).

28. Kauffman, S. L.: Acceleration of canalicular development in lungs of fetal mice exposed transplacentally to dexamethasone. Lab. Invest., 36: 395 (1977)

29. Kikkawa, Y., Motoyama, E. K., and Cook, C. D.: The ultrastructure of the lungs of lambs. The relationship of osmiophilic inclusions and alveolar lining layer to fetal maturation and experimentally produced respiratory distress. Am. J. Pathol., 47: 877 (1965)

30. Liggins, G. C.: Premature delivery of foetal lambs infused with glucocorticoids. J. Endocrinol., 45: 515 (1969).

31. Liggins, G. C., and Howie, R. N.: A controlled trial of antepartum glucocorticoid treatment for prevention of the respiratory distress syndrome in premature infants. Pediatrics, 50: 515 (1972).

32. Mescher, E. J., Platzker, A. C. G., Ballard, P. L., Kitterman, J. A., Clements, J. A., and Tooley, W. H.: Ontogeny of tracheal fluid, pulmonary surfactant and plasma corticoids in the fetal lamb. J. Applied Physiol., 39: 1017 (1975).

33. Motoyama, E. K., Orzalesi, M. M., Kikkawa, Y., Kaibara, M., Wu, B., Zigas, C. J., and Cook, C. D.: Effect of cortisol in the maturation of fetal rabbit lungs. Pediatrics, 48 : 547 (1971).

34. Nathanielsz, P. W., Comline, R. S., Silver, M., and Paisley, R. B.: Cortisol metabolism in the fetal and neonatal sheep. J. Reprod. Fertil. (suppl.), I6: 39 (1972).

35. Nathanielsz, P. W., Comline, R. S., Silver, M., and Thomas, A. L.: Thyroid function in the foetal lamb during the last third of gestation. J. Endocrinol., 58: 535 (1973).

36. Peterson, R. E.: The influence of the thyroid on adrenal cortical function. J. Clin. Invest., 37: 736 (1958).

37. Platzker, A. C. G., Kitterman, J. A., Mescher, E. J., Clements, J. A., and Tooley, W. H.: Surfactant in the lung and tracheal fluid of the fetal lamb and acceleration of its appearance by dexamethasone. Pediatrics, 56: 554 (1975).

38. Redding, R. A., Douglas, W. H. J., and Stein, M.: Thyroid hormone influence upon surfactant metabolism. Science, 175: 994 (1972).

39. Redding, R. A., and Pereira. C.: Thyroid function in respiratory distress syndrome (RDS) of the newborn. Pediatrics, 54: 423 (1974).

40. Richards, G. M.: Modifications of the diphenylamine reaction giving increased sensitivity and simplicity in the estimation of DNA. Anal. Biochem., 57: 369 (1974).

41. Rooney, S. A., Gross, I., Gassenheimer, L. N., and Motoyama, E. K.: Stimulation of glycerolphosphate phosphatidyltransferase activity in fetal rabbit lung by cortisol administration. Biochim. Biophys. Acta, 398: 433 (1975)

42. Rooney, S. A., Gobran, L., Gross, I., Wai-Lee, T. S., Nardon, L. L., and

Copyright $@ 1979$ International Pediatric Research Foundation, Inc. $0031-3998 / 79 / 1304-0230 \$ 02.00 / 0$
Motoyama, E. K.: Studies on pulmonary surfactant. Effect of cortisol administration to fetal rabbits in lung phospholipid content, composition and biosynthesis. Biochim. Biophys. Acta, 450: 121 (1976).

43. Schacterle, G. R., and Pollack, R. L.: A simplified method for the quantitative assay of small amounts of protein in biologic material. Anal. Biochem., 51: 654 (1973).

44. Schultz. F. M., Jimenez, J. M., MacDonald, P. C., and Johnston, J. M.: Fetal lung maturation. I. Phosphatidic acid phosphohydrolase in rabbit lung. Gynecol. Invest., 5: 222 (1974).

45. Skipski, V. P., Peterson, R. F., and Barclay, M.: Quantitative analysis of phospholipids by thin-layer chromatography. Biochem J., 90: 374 (1964).

46. Smith, B. T., Torday, J. S., and Giroud, C. J. P.: The growth promoting effect of cortisol on human fetal lung cells. Steroids, 22: 515 (1973).

47. Smith, B. T., and Torday, J. S.: Factors affecting lecithin synthesis by fetal lung cells in culture, Pediatr. Res., $8: 848$ (1974).

48. Smith, B. T., Torday, J. S., and Giroud, C. J. P.: Evidence for different gestationdependent effects of cortisol in cultured fetal lung cells. J. Clin. Invest., 53: 1518 (1974).

49. Solomon, S.: Fetal hormones in pulmonary maturation and metabolism of steroids by fetal lung. Agents Actions, 6: 516 (1976).

50. Spitzer, H. L., Rice, J. L., MacDonald, P., and Johnston, J. M.: Phospholipid biosynthesis in lung lamellar bodies. Biochem. Biophys. Res. Commun., 66: 17 (1975).

51. Thorburn. G. D., and Hopkins, P. S.: Thyroid function in the foetal lamb. In: K. S. Comline, K. W. Cross, G. S. Dawes, and, P. W. Nathaniels, Foetal and Neonatal Physiology: Proceedings of the Sir Joseph Barcroft Centenary Symposium, p. 448 (Cambridge University Press, London 1973).

52. Thorburn, G. D.: The role of the thyroid gland and kidneys in fetal growth. Ciba Found. Symp. 27: 185 (1974).

53. Torday, J. S., Smith, B. T., and Giroud, C. J. P.: The rabbit fetal lung as a glucocorticoid target tissue. Endocrinology, 96: 1462 (1975).

54. Wu, B., Kikkawa, Y., Orzalesi, M. M., Motoyama, E. K., Kaibara, M., Zigas, C. J., and Cook, C. D.: The effect of thyroxine on the maturation of fetal rabbit lungs. Biol. Neonate, 22: 161 (1973).

55. The authors thank Allen Nakagawa, Chris Squire, and Paula Colbert for technical assistance and Betsie Weider and Marsha Wilson for preparation of the manuscript.

56. This research was supported by the United States Public Health Grant : $;$, 2OI HD09677 from the National Institute of Child Health and Human Development. Dr. Erenberg is a recipient of a Research Career Development Award 1 K04 HD00I55 from the National Institute of Child Health and Human Development.

57. Requests for reprints should be addressed to: Allen Erenberg, M.D., Department of Pediatrics, University of lowa Hospitals and Clinics lowa City, Io 52242 (USA).

58. Received for publication November 15, 1977.

59. Accepted for publication May 3, 1978. 